\title{
DO INCOME SM00THING PRACTICES EXPLAIN THE LOWER EARNINGS-PRICE RATIO OF JAPANESE FIRMS COMPARED TO THOSE OF THE U.S. FIRMS?
}

\author{
Indra Wijaya Kusuma
}

This study examines the variation in earnings-price ratios across Japanese and U.S. firms. The earnings-price ratio is one of the indicators often used by investors to determine their trading strategy. Previous literature document that Japanese firms have consistently lower earnings-price ratios than U.S. firms even though the earnings of Japanese firms have been adjusted to the U.S. GAAP. The objective of this study is to show that Japanese firms engage in income smoothing practices that stabilize earnings, thereby increasing Japanese investors' willingness to pay higher prices for Japanese stocks.

Comparing the income smoothing index and proportion of firms identified as smoothers shows that the intensity of Japanese firms practicing income-smoothing is greater than that of U.S. firms. The results also show that income-smoothing index is significant in explaining the cross-sectional variation of earningsprice ratios for Japanese firms but it is not significant for U.S. firms. Two potential explanations for the results of U.S. firms are as follows. First, income smoothing is not practiced widely across firms in the U.S. Therefore, the variation of income smoothing does not explain the variation in the cross-sectional earnings-price ratios. Second, even if U.S. firms practice income smoothing, the investors are aware of it and do not take earnings figures literally. 
Gadjah Mada InternationalJournal of Business, January-April 2005, Vol. 7, No. 1

\begin{abstract}
Another results show that controlling for income smoothing does not eliminate the differences in the earnings-price ratios of the Japanese and U.S. firms. It is appropriate to conclude that although income smoothing plays a role in explaining the variations of earnings-price ratios across Japanese firms, it is not the only factor that contributes to the differences in the earnings-price ratios of Japanese and U.S. firms. Other factors may play a role which are either country-specific (such as inflationary expectations, tax regimes) or firm-specific (such as quality of earnings, real returns) as suggested by Brown (1989). The overall results are consistent across samples.
\end{abstract}

Keywords: earnings price ratio; income smoothing, Japanese earnings adjustment, Japanese firms; U.S. firm

\section{Introduction}

Since international capital markets are now highly integrated, Brown (1989) suggests that a prime candidate for research in the globalization of capital markets is explaining the differences in the price-earnings ratios of listed companies in different countries. Business Week (July 17, 1989) tabulates the average price-earnings ratios of firms in the ten countries represented in the Global 1000 index. The average price-earnings ratio of Japanese firms is 100 compared to an average price-earnings ratio for U.S. firms of 21 . The price-earnings ratio is one of the indicators often used by investors to determine their trading strategy. Therefore, it is interesting to do studies on Japan which has the greatest disparity in the average price-earnings ratio relative to the U.S.

Several explanations for the differences in price-earnings ratio between Japanese and U.S. firms have been proposed. Shapiro (1996) and Frankel (1991) argue that a high Japanese price-earnings ratio is a result of its lower cost of capital. However, even though the gap in the cost of capital between Japan and the U.S. has closed, the average price-earnings ratio of Japanese firms still remains significantly higher than that of the U.S. Choi and Mueller (1992) contend that the high price-earnings ratio in Japan is mainly attributed to differences in underlying financial accounting standards. However, French and Poterba (1991), Aron(1991), and Kusuma (2004a) find that accounting differences explain only about half the long-run disparity between Japanese and the U.S. priceearnings ratios.

Hence, it is clear that although all the explanations above are valid, together they do not completely explain the gap in the price-earnings ratios between Japanese and U.S. firms. The objective of this study is to show that differences in the accounting standards 
have two distinct but complementary effects. That is, differences in the accounting standards can affect the earnings-price ratio ${ }^{1}$ directly through its effect on the measurement of earnings, and more importantly, indirectly through the effect of investors' perceptions about earnings variability on price.

In particular, accounting standards allow companies to choose methods that facilitate income smoothing practices by managers. Income smoothing is an intentional dampening of fluctuations around some level of earnings that is considered to be normal for a firm(Goodwin 1977). Income smoothing enables companies to stabilize earnings and thereby increase earnings predictability. Investors are more likely to price higher the stocks of companies that have earnings stability and predictability.

Luttman and Silhan (1995) find that a stable income pattern is consistently related to earnings predictability. Subramanyam (1996) finds that income smoothing improves the persistence and predictability of reported earnings. In addition, Wang and Williams (1994) document that smoothed income numbers are viewed favorably by the markets because firms with smoother income are perceived as being less risky. These findings suggest that income smoothing can be beneficial to both existing stockholders and prospective investors. It is interesting to examine whether the accounting standards in Japan that facilitate incomesmoothing practices by Japanese companies is a possible explanation for the gap between Japanese and U.S. earnings-price ratios. This is an issue not previously explored in the literature.

This study will answer a research question: Do differences in income smoothing intensity between Japanese and U.S. firms explain differences in the earnings-price ratio between Japanese and U.S. firms?

\section{Brief Literature Review}

Prior research argues that differences in accounting standards between the U.S. and Japan are primarily responsible for the differences of the earnings-price ratios. This study attempts to show that income-smoothing practices also contribute to the low earnings-price ratios of Japanese firms relative to U.S. firms. Income smoothing practices create a stable income pattern which minimizes uncertainty in the perception of investors (Goodwin 1977). Stable income pattern and reduced earnings variability is consistently related to earnings predictability

\footnotetext{
${ }^{1}$ The earnings-price ratio is the reciprocal of price-earnings ratio which is calculated as the stock price per share divided by earnings per share (Foster, 1986). I use the term earnings-price ratio consistently in this study and use the term price-earnings ratio only to summarize results in previous literature. The use of price-earnings ratio will create an econometric problem in the regression since the low earnings (approaching zero) will cause the price-earnings ratio becomes very large (approaching infinity), therefore creating a non-constant error (heteroskedastic) problem.
} 
(Luttman and Silhan 1995). Further, earnings predictability can affect investment decisions and stock prices.

\section{Measurement Effects of Accounting Standard Differences}

Several studies examine accounting standard differences and whether these differences matter. The studies by Craiget al. (1987), Fuhrman(1988), Bricker, et al (1995), Aron (1991), French and Poterba (1991), and Kusuma (2004a) examine the impact of the accounting standard differences on earnings and the earnings-price ratio.

Craig et al. (1987) examine whether firms which use conservative accounting methods tend to have higher price-earnings ratios than firms that use less conservative accounting methods. The results indicate that firms which use conservative accounting methods for inventory and tax credits tend to have significantly higher priceearnings ratios than firms that use less conservative methods. This evidence shows that differences in accounting methods (more conservative versus less conservative) could result in differences in price-earnings ratios (see also Beaver and Morse 1978).

Fuhrman (1988) discusses the interpretation of the price-earnings ratio in different countries. Fuhrman (1988) states that outside the U.S., a priceearnings ratio could mean something very different from what it does on Wall Street. In other countries, earnings are distorted by accounting con- ventions that make cross-country comparisons difficult. In the case of Japan, the Tokyo Stock Exchange is the world's single largest (in terms of market capitalization) stock market and is the most overpriced by U.S. standards. Japanese price-earnings ratios are the highest among countries including the U.S., Germany, Switzerland, Italy, the U.K., France, Netherlands, and New Zealand.

Bricker et al. (1995) investigate financial analyst interpretations of earnings quality and their preference for accounting methods. The results show that analysts associated high earnings quality with near-term earnings predictability. This predictability is defined in an economic sense in terms of a low level of earnings volatility, and in the accounting sense in terms of management discretion over the establishment and adjustment of certain conservative reserves, allowances, and offbalance-sheet assets. The study also finds limited association between earnings quality and the application of conservative accounting methods.

Aron (1991) examines Japanese price-earnings ratio in an environment of increasing uncertainty. In a comparison of Japanese and the U.S. priceearnings ratios, Aron (1991) argues that a common framework of accounting and of earnings capitalization is required. Using a sample from Morgan Stanley Capital International Perspective (MSCIP), Aron (1991) adjusts Japanese price-earnings ratios for differences in accounting standards (reserves, consolidation, and depreciation) and for differences in cross-hold- 
ing and capitalization of earnings. Using data from MSCIP index, the Japanese original average price-earnings ratio is about 34.30 times compared to the average U.S. price-earnings ratio of about 14.60 times. After adjustment for differences in accounting standards, the Japanese price-earnings ratios reduce to 22.62 times. Thus, after the adjustment, the price-earnings ratios of Japanese firms are still higher than those of the U.S.

French and Poterba (1991) investigate the reason for high Japanese price-earnings ratios compared to the U.S. French and Poterba (1991) attempts to adjust Japanese firms earnings to eliminate the differences in the accounting standards between Japan and the U.S. Three major items adjusted are: (1) consolidation and intercorporate ownership; (2) special reserves; and (3) depreciation. French and Poterba (1991) show that accounting differences explain about half of the long run disparity between the U.S. and Japanese price-earnings ratios.

Moreover, Kusuma (2004a) reexamines the differences in the earningsprice ratios of Japanese and U.S. firms. Kusuma (2004a) also finds that adjusting the Japanese earnings to U.S. GAAP reduces the differences in the earningsprice ratios of Japanese and U.S. firms by 52 percent. Kusuma (2004a) uses the same adjustment items in the French and Poterba (1991).

In summary, several studies examine the impact of accounting standard differences on the earnings and earnings-priceratio. Those studies show that Japanese accounting standards result in a more conservative figure of earnings, and as a result, a higher figure of price-earnings ratio. However, even after adjusting Japanese earnings to the U.S. standards, the difference in the price-earnings ratio is still persisted.

\section{Cross-Sectional Variation of Earnings-Price Ratios}

Most studies in this area relate the earnings-price ratio to the theory of valuation in finance. Basically, two main factors are mostly recognized as factors which influence the earningsprice ratio across firms. Those factors are risk (discount factor price) and growth (future earnings). The studies include Beaver and Morse (1978), Cho (1994), Zarowin(1990), and Constand et al. (1991).

Beaver and Morse (1978) examine factors that determined price-earnings ratios such as earnings growth and risk to explain cross-sectional differences in the price-earnings ratio. Using rank correlation and regression methods, the results show little correlation between price-earnings ratio and present or past earnings growth. However, there is a positive correlation between the price-earnings ratio and earnings growth in subsequent years. The study also shows little correlation between price-earnings ratios and market risk beta.

Cho (1994) incorporates recent equity valuation theories to examine the determinants of cross-sectional dif- 
ferences in earnings-price ratios. Cho (1994) uses four factors to determine the price-earnings ratio: (1) risk measures; (2) growth; (3) dividend payout; and (4) earnings persistence. The results show that most of the variables are significant in determining the level of earnings-price ratios, especially the $e x$ ante measures of risk and growth, and the payout ratio. Earnings persistence is not significant. Beta is a poor proxy for ex ante risk. Ex post measures of risk and growth do not explain the variation of earnings-price ratios [consistent with the results of Beaver and Morse 1978].

Zarowin (1990) revisites study on what determines earnings-price ratios. Conventional stock valuation theory suggests that higher risk was associated with higher earnings-price ratios, and greater growth is associated with lower earnings-price ratios. Using a database not available to Beaver and Morse (1978), this study reaches significantly different conclusions from Beaver and Morse (1978). The results show that cross-sectional differences in forecasted long-term EPS growth rates are the dominant source of differences in earnings-price ratios. Beta risk and forecasted short-term growth seem to be relatively unimportant in determining earnings-price ratios.

Constand et al. (1991) examine factors affecting price earnings ratios and market values of Japanese firms. Specifically, the results show that changes in $E P$ ratios are negatively related to growth and dividend payout, but positively related to changes in land value.

In summary, relating the theory of earnings-price ratio with the theory of valuation, risk and growth are shown to be two basic factors that affect the earnings-price ratio. Several studies document that earnings-price ratio is positively correlated with risk and negatively correlated with growth

\section{Income Smoothing}

Several studies by Trueman and Titman (1988), Wang and Williams (1994), Huberts and Fuller (1995), Michelson et al. (1995), and Bitner and Dolan (1996) examine the market reaction to the income smoothing practices. One study, Sheikholeslami (1994) specifically examines Japanese income smoothing practices.

Trueman and Titman (1988) attempt to explain why smoothing might be observed and how it can result in an increased stock price. If a manager can choose which of two periods to recognize certain income, the manager might prefer the choice that will be expected to result in a smoother income stream. By smoothing income the manager might be able to reduce the estimate of various claimants of the firm about the volatility of its underlying earnings process. This, in turn, will lower the assessment of the probability of bankruptcy and increase the stock price.

Wang and Williams (1994) examine the relationship between accounting income smoothing and stockholder 
wealth. Their study argues that, contrary to common belief, income smoothing actually enhances the informational value of earnings. The process of income smoothing incorporates manager's private knowledge regarding the firm's future prospects. The extent to which a manager can smooth the firm's reported income reflects the accuracy of the manager's knowledge of firm's future performance. This revelation of management private knowledge is valuable to investors. The results of this study indicate that smoothed income numbers are viewed favorably by the markets and firms with smoother income series are perceived as being less risky.

Huberts and Fuller (1995) investigate predictability bias in an assetpricing framework. Firms, whose earnings are not predictable in the past, have excessively optimistic current forecast of earnings. The least predictable firms have much larger positive forecast errors relative to the most predictable firms. Consequently, abnormal returns are consistent with the current forecast errors. Stocks of the least predictable firms substantially under-perform stocks of the most predictable firms. This predictability bias will make investors favor firms whose earnings are predictable. As a result, firms tend to smooth their income stream to increase the value of their equity shares. Subramanyam (1996) provides evidence that pervasive income smoothing improves the persistence and predictability of reported earnings.
Michelson et al. (1995) investigate the relationship between income smoothing practices and stock returns. Using a sample of 358 firms in the S\&P 500 index, the study employs models of income smoothing utilizing the coefficient of variation of four smoothing variables with respect to the coefficient of variation in sales. The results show that smoothing firms have lower betas and higher equity market value compared to firms that do not smooth income. Firms know that investors hated surprises (Hector 1989), therefore, smoothing income is one alternative to reduce the surprise effect.

Bitner and Dolan (1996) examine the theoretical basis for the relationship between smoothed income and equity market valuation. The model yields two hypotheses: (1) equity markets should pay a premium for smooth streams of income; and (2) market valuation distinguishes earnings streams that are naturally smooth versus those that are managed. The empirical results support both hypotheses.

Sheikholeslami (1994) examines the income smoothing practices of Japanese firms listed on foreign stock exchange with locally listed Japanese firms. This study hypothesizes that Japanese firms' income-smoothing practices are altered when firms listed their stocks on foreign stock exchange with more stringent accounting requirements than their local exchanges. The sample of foreign listed Japanese firms consist of ten Japanese firms listed in New York, two in London, and twelve in Amsterdam for a total of twenty-four 
firms. A control group of locally listed twenty-four firms is used as a comparison. Unfortunately, the results do not support the hypothesis. The results might be driven by the small number of firms, especially from the New York Stock Exchange (10 firms), in the sample. In addition, most of the shares of Japanese firms listed in New York Stock Exchange are in the form of AmericanDepository Receipts (ADRs), which do not require compliance with SEC's regulations.

In summary, some studies examine the impact of accounting standard differences on the earnings and earnings-price ratio. Those studies show that Japanese accounting standards result in a more conservative figure of earnings, and as a result, a higher figure of price-earnings ratio. However, even after adjusting Japanese earnings to the U.S. standards, the difference in the price-earnings ratio still persists. Risk and growth are shown to be two basic factors that affect the earnings-price ratio. Earnings-price ratio is positively correlated with risk and negatively correlated with growth. Managers know that investors prefer smoothed income numbers for several reasons: (1) smoothed income numbers reduce the estimate of various claimants of the firm about the volatility of its underlying earnings process and thereby reduce the assessment of the probability of bankruptcy); (2) income smoothing reflects the accuracy of the manager's knowledge of the firm's future performance; (3) investors hate shocks because shocks in earnings forecasts increased investors' risk. The empirical evidence supports the argument that income smoothing has a positive impact on stock returns.

\section{Hypotheses Development}

Accounting standard adjustments focus only on the earnings component of the earnings-price ratio. However, a low average earnings-price ratio for Japanese compared to U.S. firms may reflect the relative willingness of Japanese investors to apply a low rate of discount to a given earnings level. In particular, the average earnings-price ratio is relatively low not because earnings is low but because share price is relatively high. Therefore, there are two forces that cause the lower earnings-price ratios of Japanese firms. First, the conservatism of the Japanese accounting standards leads to lower earnings. Second, the conservatism is perceived having higher earnings quality, therefore investors are willing to pay the premium on the price.

The conjecture in this research is that investors are willing to pay a higher pricefor Japanese stocks because Japanese firms employ income-smoothing practices to reduce the temporal volatility in earnings. Wang and Williams (1994) show that the market perceives smoothed income numbers as being less risky. Moreover, as Foster (1986) argues, lower earnings variability might signal high management quality. In addition, as Trueman and Titman(1988) and Hector (1989) point out, investors are willing to pay a higher price for 
firms that smooth income because the risk of financial distress is lower. Srinidhi et al. (2001) argue that market imperfections could cause income smoothing if the manager is privately better informed about future prospects. The extent of income smoothing is shown to increase with the accuracy of foresight information.

Nagy and Neal (2001) examine whether differences in the corporate environments of Japanese and U.S. firms are associated with differences in the extent of engaging in corporate myopic behavior through income smoothing. They find that both Japanese and U.S. firms engage in some amount of myopic behavior but Japanese firms do so at a significantly higher level. Considering that Japanese firms can manage earnings through its accounting practice (special purpose reserve as an example, discretionary R\&D expenditure or through accounting changes as examined by Douglas1987, Suh1990, and Mande et al. 2000), Kusuma (2004b) examines the income smoothing intensity of Japanese and U.S. firms and finds that Japanese firms smooth income more intensively compared to their counterparts in the U.S.

If Japanese firms practice income smoothing more intensely than U.S. firms, then it is necessary to examine the impact of income smoothing to the earnings-price ratios. Based on the argument given that income smoothing is responded positively, it leads to the first hypothesis as follows.
$\mathrm{H}_{\mathbf{A} 1}$ : Within each country, incomesmoothing index explains the crosssectional variation of earningsprice ratios.

From a cross-sectional earningsprice ratio model described in the next section, the hypothesis and its alternative can be stated as follows.

$$
H_{01}: \gamma_{\mathrm{k}}=0 ; \text { and } H_{A 1}: \gamma_{\mathrm{k}} \neq 0
$$

where,

$k=1,2$ denote Japan and U.S. respectively and $\gamma$ denotes the coefficient of income smoothing index in the crosssectional earnings-price ratio regression.

For each country, earnings-price ratios are regressed against income smoothing index, growth proxy, risk proxy, and two control variables, such as sizes and dividend payout ratios. It is expected also that the coefficient of income smoothing for Japanese firms is higher (in absolute value) than the coefficient for U.S. firms since income smoothing practices are expected to be more intensely practiced in Japan.

Finally, while the earnings-price ratios depend on income smoothing index, growth, and risk, it is expected that conditioning on income smoothing index, risk, and growth, the difference in the average earnings-price ratio of Japanese and U.S. firms will disappear. Therefore, the second hypothesis is formed in the null hypothesis as follows.

$\mathrm{H}_{\mathbf{0 2}}$ : After controlling for income smoothing index, risk, and growth 
Gadjah Mada InternationalJournal of Business, January-April 2005, Vol. 7, No. 1

factors, the average of earningsprice ratio of Japanese firms is equal to that of U.S. firms.

From the cross-sectional earningsprice ratio model, the hypothesis and its alternative can be stated as follows.

$$
H_{02}: \alpha_{1}=\alpha_{2} ; \text { and } H_{A 2}: \alpha_{1} \neq \alpha_{2}
$$

where,

$$
\begin{aligned}
& k=1,2 \text { denote Japan and the U.S. re- } \\
& \text { spectively. }
\end{aligned}
$$

\section{Models}

Two main models are used in this study: income smoothing index and cross-sectional model of earnings-price ratio.

\section{Income Smoothing Index}

The ratio of the coefficient of variation of sales to the coefficient of variation of earnings has been used as a proxy for income smoothing [see Imhoff (1977), Eckel (1981), Albrecht and Richardson (1990), and Ashari et al. (1994)]. Since sales are less subject to manipulation, the lower degree of coefficient of variation of earnings compared to coefficient of variation of sales indicates income smoothing.

The coefficients of variation $(\mathrm{CV})$ of sales and earnings are calculated as follows.

$$
C V_{i}^{\text {sales }}=\frac{\sigma_{i}^{\text {sales }}}{\bar{X}_{i}^{\text {sales }}}
$$

and

$$
C V_{i}^{\text {earnings }}=\frac{\sigma_{i}^{\text {earnings }}}{\overline{|X|_{i}^{\text {earnings }}}}
$$

where:

$\sigma_{i}^{\text {sales }}$ and $\sigma_{i}^{\text {earnings }}$ are the standard deviations of sales and earnings series for firm $i$;

$\bar{X}_{i}^{\text {sales }}$ and $\overline{|X|}_{i}^{\text {earnings }}$ are the means of sales and the absolute value of the means of earnings series for firm $i$;

$C V_{i}^{\text {sales }}$ and $C V_{i}^{\text {earnings }}$ are the coefficients of variation of sales and earnings for firm $i$.

The income-smoothing index is calculated as follows.

$$
I S_{i}=\frac{C V_{i}^{\text {sales }}}{C V_{i}^{\text {earnings }}}
$$

where,

$C V_{i}^{\text {sales }}$ and $C V_{i}^{\text {earnings }}$ are the coefficients of variation of sales and earnings for firm $i$;

$I S_{i}$ is the income smoothing index for firm $i$.

A smoothing index greater than one indicates the income smoothing since the coefficient of variation of sales is greater than coefficient of variation of earnings.

\section{Cross-Sectional Model of Earnings-Price Ratio}

The two pricing factors that affect the earnings-price ratio are risk and growth (Zarowin 1990; and Cho 1994). 
In a valuation context, risk captures the discount (interest) factor; and growth, the expected future dividends or earnings factor. For each country $k=1,2$, the earnings-price ratio model is estimated across firms $i$.

$$
\begin{gathered}
E P R_{i k}=\alpha_{k}+\gamma_{k}(I S)_{i k}+\delta_{k}(G)_{i k}+ \\
\beta_{k}(R)_{i k}+\lambda_{k}(C)_{i k}+\varepsilon_{i k}
\end{gathered}
$$

where,

$E P R$ ik is the earnings-price ratio for firm $i$;

$I S_{i k}$ is the income smoothing index for firm $i$;

$R_{i k} \quad$ is the risk proxy for firm $i$;

$G_{i k} \quad$ is the growth proxy for firm $i$; and

$C_{i k} \quad$ is the size and dividend payout ratio for firm $i$.

Financial leverage is used as a proxy for risk. Financial leverage captures the financial risk of the firm. Financial leverage is obtained by dividing total debt by total debt plus total equity.

$$
F L_{i t}=\frac{T D_{i t}}{\left(T D_{i t}+M V_{i t}\right)}
$$

where,

$F L_{i t}$ is financial leverage for firm $i$ and time $t$;

$T D_{i t}$ is total debt for firm $i$ and time $t$; and

$M V_{i t}$ is total equity for firm $i$ and time $t$.
Market-to-book ratio is used as a proxy of growth. The market to book value is calculated as follows.

$$
\text { Growth }_{i t}=\frac{M V_{i t}}{B V_{i t}}
$$

where,

$M V_{i t}$ is market value of equity for firm $i$ and time $t$;

$B V_{i t}$ is book value of equity for firm $i$ and time $t$.

Two control variables are used in this study. The control variables are size and dividend-payout ratio. These two variables are used in the crosssectional earnings-price regression in the previous literature. Natural-log form of market capitalization is used as a proxy for size. Market capitalization is obtained by multiplying price per share to outstanding shares. The market capitalization is obtained as follows.

$$
M V_{i t}=P P S_{i t} \square S H O_{i t}
$$

where,

$M V_{i t}$ is the market capitalization for firm $i$ and period $t$;

$P P S_{i t}$ is the market price per share for firm $i$ and period $t$; and

$S H O_{i t}$ is the number of shares outstanding for firm $i$ and period $t$.

Dividend-payout ratio is obtained by dividing total dividends to total earnings. The dividend-payout ratio is calculated as follows.

$$
D P R_{i t}=\frac{\text { Dividends }_{i t}}{\text { Earnings }_{i t}}
$$


where,

$\begin{array}{ll}D P R_{i t} & \begin{array}{l}\text { is the dividend-payout ra- } \\ \text { tio for firm } i \text { and period } t ;\end{array} \\ \text { Dividends } s_{i t} & \text { is the total dividends for } \\ & \text { firm } i \text { and period } t \text {; and } \\ \text { Earnings } \quad \text { it } & \text { is the total earnings for } \\ & \text { firm } i \text { and period } t .\end{array}$

\section{Data Collection and Sampling Procedures}

This study examines the earningsprice ratios for Japanese and U.S. firms over the period 1991-1995. The 1996 Compustat Global Vantage Database is used to obtain most of the financial information required, such as price per share, earnings per share, as well as data used for accounting standards adjustments. The International Institutional Brokers Estimate System
(IIBES) 1997 tapes are used to obtain forecasted earnings to compute growth.

Two criteria are used to select the sample of firms in each country. First, the firms must be in SIC codes 20003900 (manufacturing group). Second, data on these firms are available both in the Global Vantage Database and IIBES tapes.

Table 1 shows the sampling procedures and the number of firms available. The initial number of the U.S. firms from the Global Vantage database for manufacturing group is 1323 firms. From 1323 firms, only 1033 firms have complete data for five years. Only 553 firms (54\%) have all positive earnings price ratios during the fiveyear period. The initial number of the Japanese firms from the Global Vantage database for manufacturing group is 726 firms. From 726 firms, only 575

Table 1. Sample Selection Procedures

\begin{tabular}{|c|c|c|}
\hline & Japan & U.S. \\
\hline Total manufacturing firms from Global Vantage a & 726 & 1323 \\
\hline less: E/P ratio not available during $1991-1995^{\text {b }}$ & 151 & 290 \\
\hline Firms with 5 year E/P ratios available & 575 & 1033 \\
\hline less: $\mathrm{E} / \mathrm{P}$ negative ${ }^{\mathrm{c}}$ & 127 & 480 \\
\hline Firms with all positive E/P ratios & 448 & 553 \\
\hline less: other data not available ${ }^{\mathbf{d}}$ & 83 & 154 \\
\hline Firms with all complete data & 365 & 399 \\
\hline
\end{tabular}

Notes:

a Manufacturing firms with SIC code 2000-3999

b Firms that do not have complete E/P ratios during 1991-1995 are excluded

c Firms that have at least one negative E/P ratio during 1991-1995 are excluded

d Firms that do not have complete data on other variables such as growth, risk, size, dividendpayout ratio. However, some of these firms are still included in the analysis if the required data on certain variables are available 
firms have complete data for five years. As many as 448 firms (78\%) have all positive earnings-price ratios during the five-year period. The higher percentage of Japanese firms having all positive earnings-price ratios during the five-year period confirms the indication that Japanese firms practice income smoothing.

Table 2 shows the comparison of adjusted earnings-price ratios of Japanese and U.S. firms. From previous studies, it is known that the average Japanese earnings-price ratio is lower than the average U.S. earnings-price ratio. After adjustments for differences in accounting standards, the differences in the earnings-price ratios of Japanese and U.S firms are still persisted.

Since this study focuses on the cross-sectional earnings-price ratios, the average of each firm earningsprice ratio as well as other variables are used in the regression. Pooling crosssectional and time-series is not used because the interpretation of the results may be difficult.

Table 3 shows the descriptive statistics (average of five years) of sample firms. The average earnings-price ratio of Japanese firms is significantly lower than that of the U.S. The average income-smoothing index of Japanese firms is higher than that of the U.S.

Interestingly, proxy for growth is lower for Japanese firms compared to growth for U.S. firms. This is counterintuitive since Japanese firms are expected to show higher growth. In term of risk, as expected, Japanese firms show higher financial risk (leverage) than its counterparts in the U.S.

For size (market capitalization), it is expected that the data are not normally distributed. The mean is much higher than the median for both countries. The average market capitalization for Japanese firms (\$759 million) is twice the market capitalization for U.S. firms (\$468 million). When the mean is used for the comparison, the average of market capitalization for Japan (\$2192 million) is lower than the average market capitalization for the U.S. (\$2962 million). In terms of dividend-payout ratio, the two countries show almost similar ratios based on the median and Japanese firms show lower dividend-payout ratios based on the mean.

Price per share in the U.S. is higher than price per share in Japan. The lower price per share in Japan may cause the Japanese firms earnings-price ratios to be more sensitive to the changes in unit price. To manage this potential problem, analyses are also done for sub-sample firms of Japanese and U.S. that have the same range of price per share. Similar results from the subsample analyses may provide consistency of the results across samples.

Two approaches of measuring the intensity of practicing income-smoothing are used. The first approach is the income smoothing index (the ratio of coefficient of variation of sales to the ratio of coefficient of variation of earnings). A higher average incomesmoothing index in one country relative to the other indicates a greater 
Gadjah Mada InternationalJournal of Business, January-April 2005, Vol. 7, No. 1

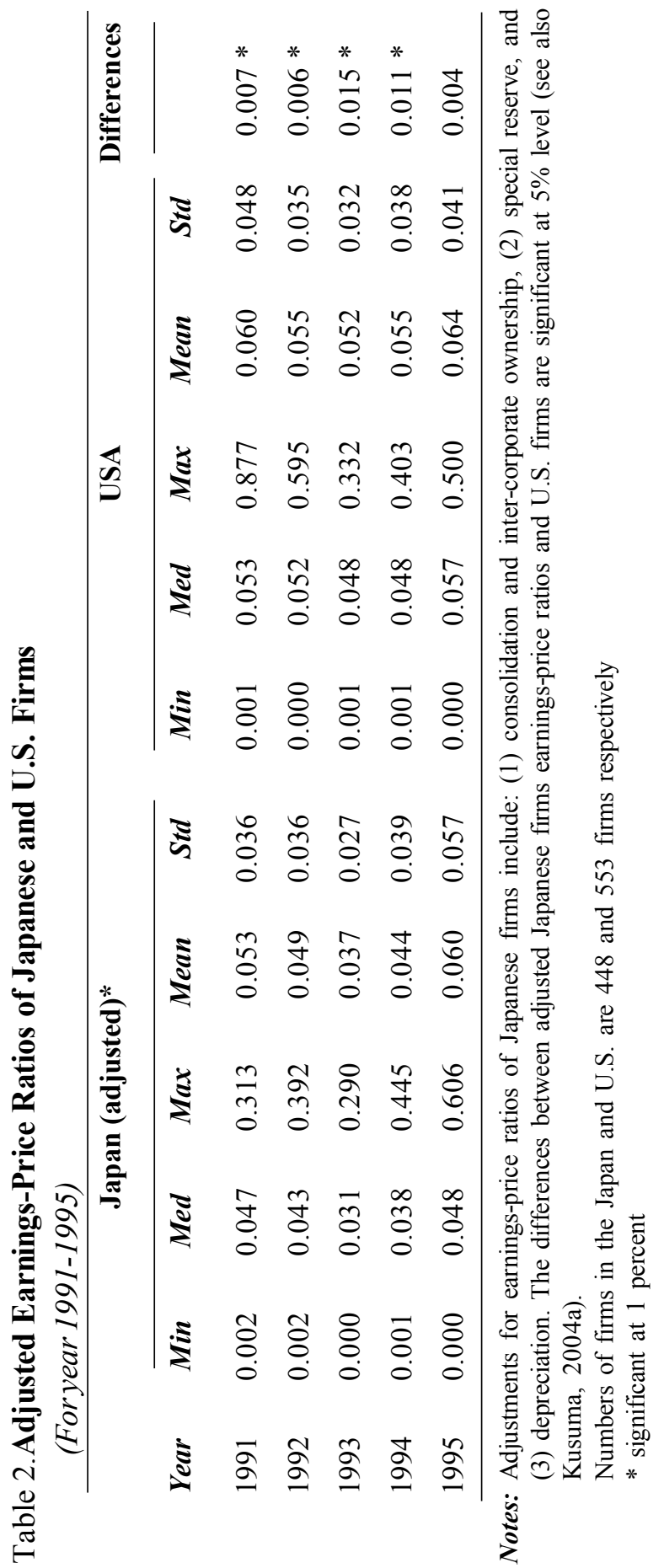


Kusuma-Do Income Smoothing Practices Explain the...

Table 3. Descriptive Statistics of Sample Firms

\begin{tabular}{|c|c|c|c|c|c|c|}
\hline & $\mathbf{N}$ & Mean & Std & Min & Max & Median \\
\hline \multicolumn{7}{|c|}{ Japanese Firms: } \\
\hline EP & 445 & 0.048 & 0.026 & 0.007 & 0.209 & 0.043 \\
\hline IS & 432 & 0.734 & 0.401 & 0.026 & 2.226 & 0.58 \\
\hline GMB & 445 & 2.404 & 1.041 & 0.96 & 7.53 & 2.13 \\
\hline $\mathrm{RF}$ & 445 & 0.420 & 0.196 & 0 & 0.94 & 0.42 \\
\hline SIZE & 445 & 2192 & 5982 & 111 & 87419 & 759 \\
\hline DPR & 445 & 0.253 & 0.206 & -0.41 & 1.91 & 0.22 \\
\hline PPS & 422 & 10.11 & 8.72 & 3.1 & 90.54 & 7.6 \\
\hline \multicolumn{7}{|c|}{ U.S. Firms: } \\
\hline EP & 553 & 0.057 & 0.028 & 0.009 & 0.48 & 0.053 \\
\hline IS & 552 & 0.665 & 0.376 & 0.006 & 2.21 & 0.63 \\
\hline GMB & 570 & 2.785 & 1.994 & -7.06 & 10 & 2.335 \\
\hline $\mathrm{RF}$ & 567 & 0.266 & 0.198 & 0 & 1.4 & 0.26 \\
\hline SIZE & 569 & 2962 & 8529 & 4.8 & 88058 & 468 \\
\hline DPR & 568 & 0.297 & 0.959 & -1.5 & 17.99 & 0.2 \\
\hline PPS & 542 & 25.88 & 19.36 & 1.9 & 242.7 & 21.7 \\
\hline
\end{tabular}

Notes:

EP : Earnings price ratio

IS : Income smoothing index

GMB : Market to book growth

RF : Financial risk

SIZE : Market capitalization

DPR : Dividend payout ratio

PPS : Price per share

propensity for that country to employ income-smoothing. The second approach is the proportion of firms identified as smoothers in each country. A firmis classified as an income smoother if its income-smoothing index is greater than one. A higher proportion of firms identified as smoothers in one country relative to the other reflect a greater propensity for that country to employ income-smoothing.

Three measures of earnings are used to compute the coefficient of variation of earnings. The first earnings measure is earnings before interest and taxes. This measure represents pretax income plus interest expense. The second measure is income before extraordinary items. This measure represents after-tax income but before extra-ordinary items. The third measure is earnings per share. This measure represents primary earnings per common share as reported by the company based on income before extraordinary items. The earnings figure used in this measure is adjusted for dividends on preferred stocks.

Table 4 shows the income-smoothing index and the proportion of firms 
Gadjah Mada InternationalJournal of Business, January-April 2005, Vol. 7, No. 1

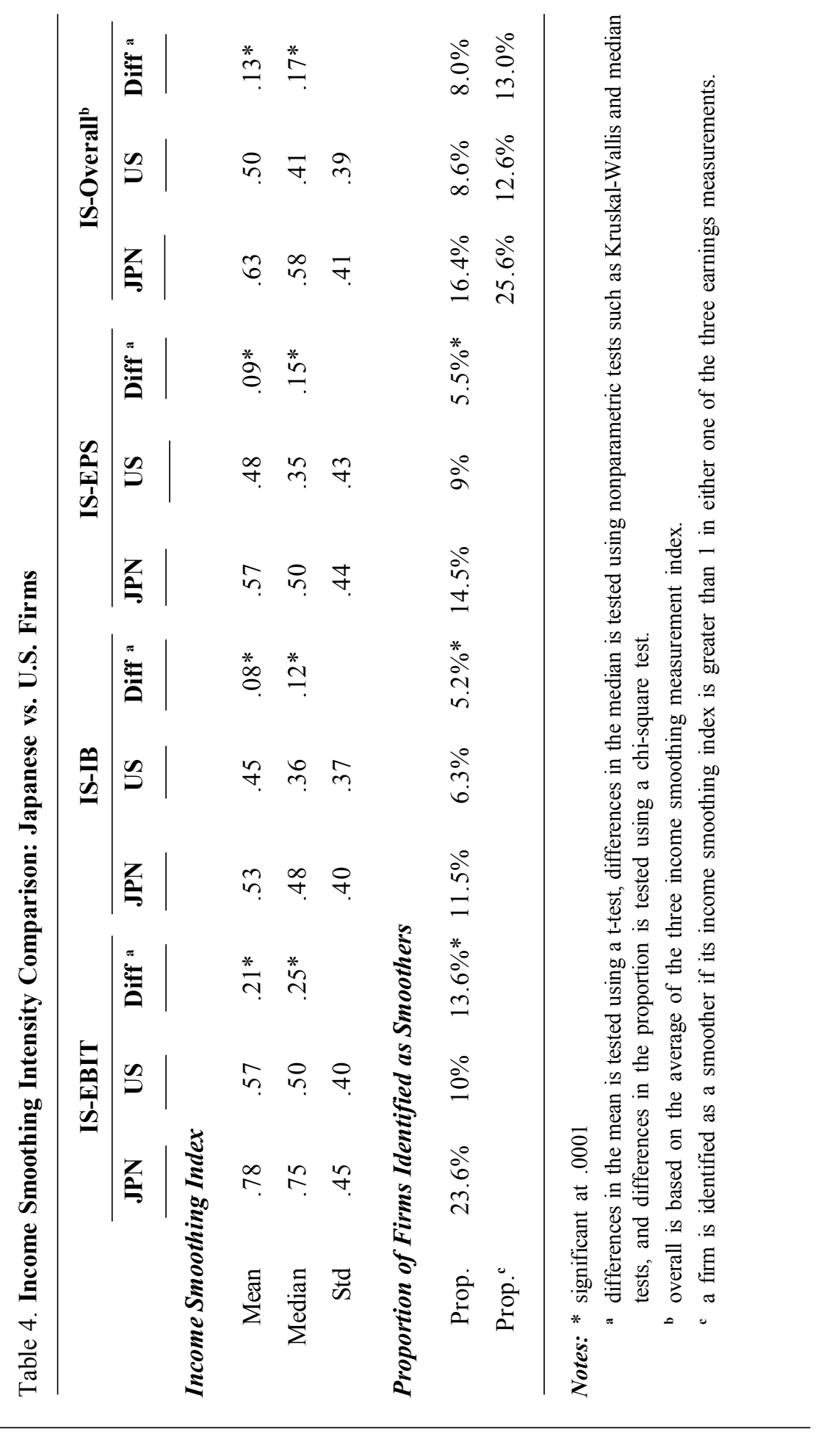


identified as smoothers for Japanese and U.S. firms. Overall, the results show that Japanese firms have higher income smoothing intensity than its counterparts in the U.S.

\section{Cross-Sectional Earnings- Price Ratios Results}

In the cross-sectional earningsprice ratios regressions, a five year average figure is used for each variable in the regression. The use of the average of five years is justified for three reasons. First, the use of pooling the cross-sectional and time-series may pose an interpretation problem because of the difficulty in separating the effects of cross-sectional versus the timeseries sets. Second, the use of timeseries alone is not possible due to the limitations of the database. Third, using the average may reduce the potential measurement error in each year alone.

In the cross-sectional regressions, the earnings-price ratios of firms in each country are regressed against the income-smoothing index, proxies for growth and risk, size, and dividend payout-ratios. The income-smoothing index used in this study is the overall income-smoothing index since this index is highly correlated with the indices based on the three measures of earnings. For Japanese firms, the overall income-smoothing index is corre- lated more than 96 percent with each of the income-smoothing indices based on the three earnings measures. For U.S. firms, the overall income-smoothing index is correlated more than 90 percent with each of the income-smoothing indices based on the three earnings measures.

In each country, two types of regressions are used: the unrestricted regression and restricted regression. The difference between the two regressions is that in the first the coefficient of the income smoothing index is unconstrained whereas in the second, the income-smoothing index coefficient is constrained to zero. A partial $F$-test ${ }^{2}$ is used to evaluate the significance of the income-smoothing index. Additional support is also evident from the percentage increase in the adjusted $R^{2}$ from the restricted regression to the unrestricted regression, and the significance of the coefficient of income smoothing index in the unrestricted regression. If the inclusion of incomesmoothing index is significant, this can be used to confirm the first hypothesis that "within each country, the incomesmoothing index explains the crosssectional variations of earnings-price ratios."

Panel A of Table 5 provides the results of the cross-sectional restricted regressions for U.S. and Japanese firms. Several interesting results are observed. The market-to-book ratios

$$
{ }^{2} \text { The partial } F \text {-test is: partial } F-\text { test }=\frac{\left(S S E_{R}-S S E_{U}\right) / 1}{S S E_{U} / d f_{U}}
$$


Gadjah Mada InternationalJournal of Business, January-April 2005, Vol. 7, No. 1

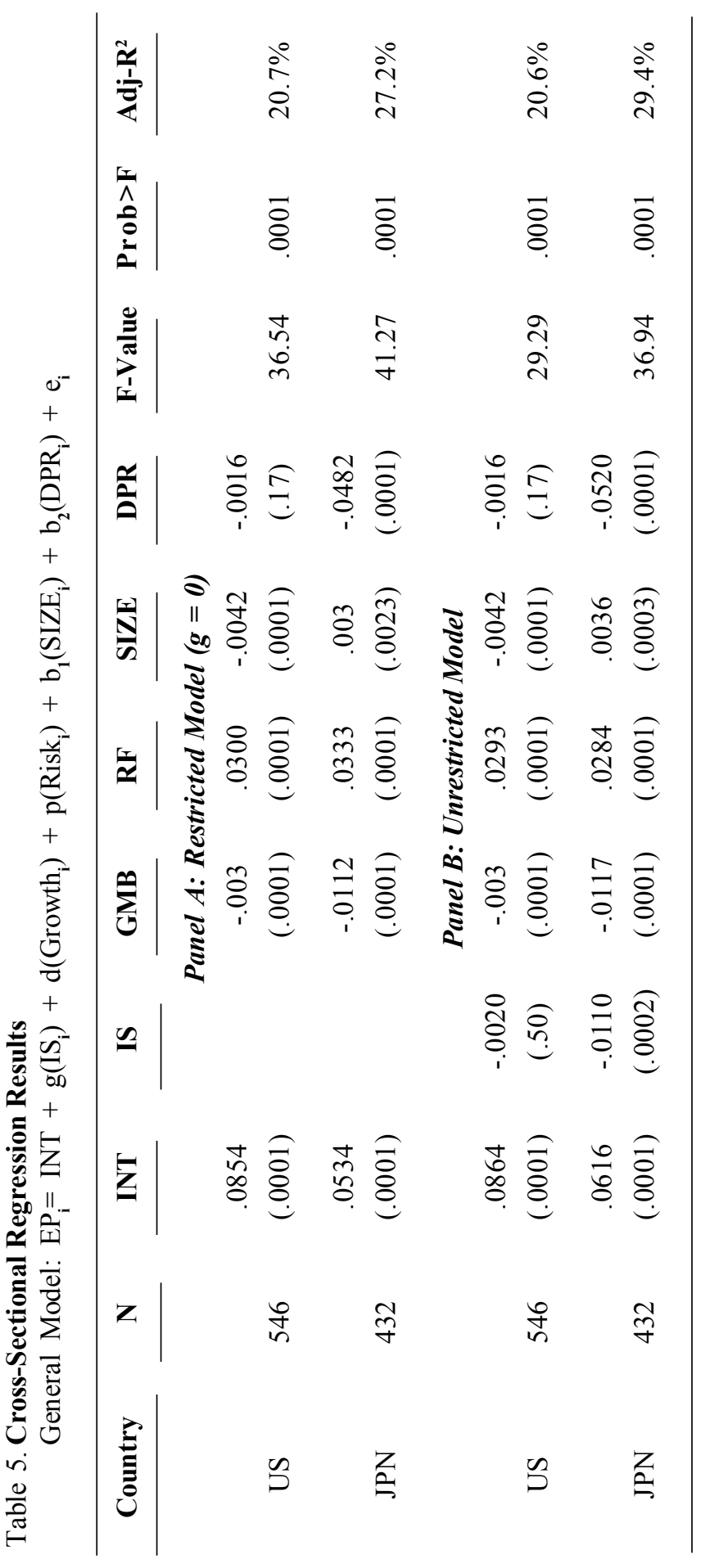


as the proxy for growth are negative and significant for both U.S. and Japanese firms (0.0001 levels). Financial risk is positive and significant at .0001 levels for both countries.

Proxy for size is negative and significant for U.S. firms, but positive and significant for the Japanese firms. A reasonable explanation for the sign difference is that size in Japan tends to proxy for risk while size in the U.S. tends to proxy for growth. In Japan, the larger firms may be interpreted as less risky, while in the U.S., larger firms are expected to have lower growth. Dividend-payout ratio is negative and only significant for Japanese firms. Surprisingly, it is not significant for U.S. firms.

The intercept is interpreted as the average earnings-price ratio conditioned on the growth, risk, size, and dividend payout ratios. The coefficients of the average conditional earningsprice ratio for U.S. and Japanese firms are .0854 and .0534 respectively.

Panel B of Table 5 provides the results of the cross-sectional unrestricted regressions for U.S. and Japanese firms. The results are consistent with the restricted regressions in Panel A. The market-to-book ratios as the proxy for growth are negative and significant for both U.S. and Japanese firms ( 0.0001 levels). Financial risk is positive and significant at .0001 levels for both countries. Proxy for size is negative and significant for U.S. firms, but positive and significant for the Japanese firms. Dividend-payout ratio is negative and only significant for Japa- nese firms and it is not significant for U.S. firms.

The coefficient on the income smoothing index is not significant for the U.S. firms ( $p$ value $=0.50$ ). On the contrary, the coefficient on the income smoothing index is negative and significant (at.0002 levels) for the Japanese firms. The negative sign is expected since the higher income-smoothing index leads to the smaller earningspriceratios. The statistical significance of the income-smoothing index coefficients shows that income-smoothing index plays a role in explaining the cross-sectional variation in the earnings-price ratios for Japanese firms.

Additional evidence is provided in Table 6. Table 6 summarizes the results of testing the significance of adding an income-smoothing index in the regressions for U.S. and Japanese firms. For the U.S. firms, the percentage change in the adjusted $R^{2}\left(\% \Delta \mathrm{R}^{2}\right)$ actually shows a decrease (from $20.7 \%$ to $20.6 \%$ ). The partial $F$-test of the restricted-unrestricted regressions shows that the adding of the restricted variable is not significant. The results show that income-smoothing is not significant in explaining the cross-sectional variation of earnings-priceratios for U.S. firms. These results do not confirm the first hypothesis that "income-smoothing index explains the cross-sectional variations of earningsprice ratio." for the U.S. firms.

On the contrary, the percentage change in the $R^{2}\left(\% \Delta \mathrm{R}^{2}\right)$ show an increase from 27.2 percent-29.4 percent. In addition, the partial $F$-test of 
Gadjah Mada InternationalJournal of Business, January-April 2005, Vol. 7, No. 1

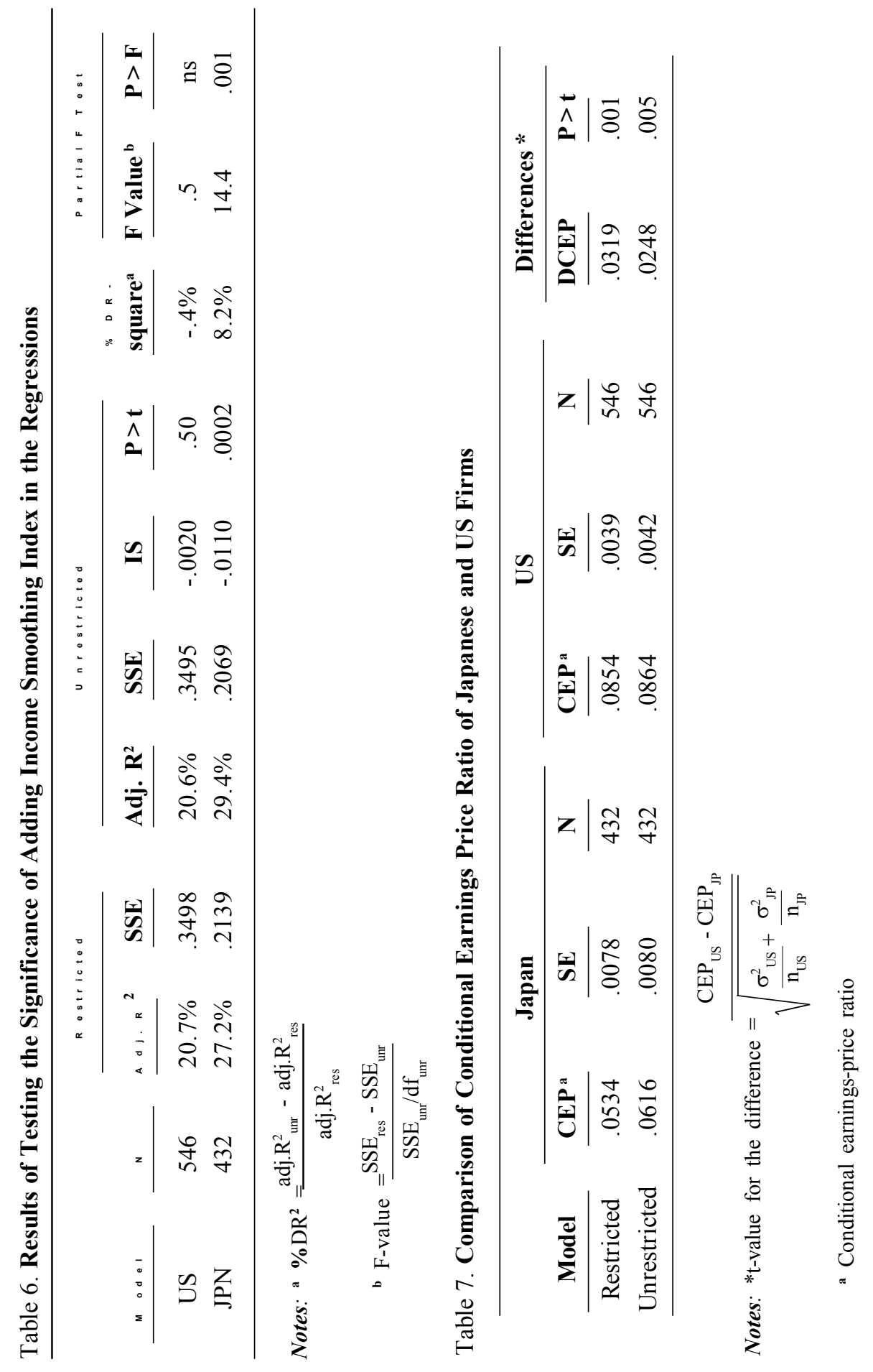


the restricted-unrestricted regressions shows the significance of the including of restricted variable, namely, the income-smoothing index variable. The results from Table 6 show that incomesmoothing is significant in explaining the cross-sectional variation of earnings-price ratios for Japanese firms. These results confirm the first hypothesis that "income-smoothing index explains the cross-sectional variations of earnings-price ratios."

The coefficients of the average conditional earnings-price ratio for U.S. and Japanese firms are .0864 and .0616 respectively. The U.S. average conditional earnings-price ratio does not change considerably from .0854 to .0864 while the Japanese average conditional earnings-price ratio changes drastically from .0534 to .0616 .

Table 7 shows the differences of the average conditional earnings-price ratios of U.S. and Japanese firms. For the restricted model, the difference ${ }^{3}$ is significant at .0001 levels. These results show that before controlling the income smoothing index, the (conditional) earnings-price ratios are lower for Japanese firms. However, after controlling for the income smoothing in the unrestricted model, the differ- ence is still significant at .0005 levels. These results suggest that although income-smoothing plays a role in explaining the variations of earnings-price ratios of Japanese firms, it is not the only factor that contributes to the differences in the earnings-price ratios of Japanese and U.S. firms. If income smoothing index is accountable for the differences of the earnings-price ratios of Japanese and U.S. firms, it is expected that the differences of conditional unrestricted earnings-price ratios of Japanese and U.S. firms will be zero (not significant). Other factors may play into a role. Those factors are country-specific, such as macro-economic (inflationary expectations, tax regimes) and firm-specific (quality of earnings, real returns) as suggested by Brown (1989). Therefore, the results in this section reject the second null hypothesis that "after controlling for income smoothing index, risk, and growth factors, the average of earnings-price ratios of Japanese firms is equal to that of U.S. firms."

Overall, the results show that income smoothing plays a role in Japan, but not in U.S. There are two possible explanations for the results. First, income smoothing is not practiced widely

${ }^{3}$ The $t$-test for the difference of conditional earnings-price ratios of Japanese and U.S. firms is:

$$
t=\frac{E P_{U S}-E P_{J P}}{\sqrt{\frac{\sigma_{U S}^{2}}{n_{U S}}+\frac{\sigma_{J P}^{2}}{n_{J P}}}}
$$


Gadjah Mada InternationalJournal of Business, January-April 2005, Vol. 7, No. 1

across firms in the U.S. Hence, the variation of income smoothing does not explain the variation in the cross-sectional earnings-price ratios in the U.S. Second, even if U.S. firms practice income smoothing, investors are aware and take it into account.

\section{Sensitivity Analysis}

To test the robustness of the results, several additional analyses are conducted. First, the forecasted earnings growth and adjusted beta are used as proxies for growth and risk in addition to market to book growth and financial leverage. Adjusted beta is expected to capture other aspect of risk, such as market risk. Although the original beta may be related to firm leverage, the adjusted beta is used in this study to capture un-levered market risk. Adjusted beta is computed in two steps. First, the beta is estimated from a market model. The market model is estimated as follows:

$$
R_{i t}=\alpha_{i}+\beta_{i}\left(R m_{t}\right)+\varepsilon_{i t}
$$

where,

$R_{i t}$ is the individual firm return at period $t$;

$R m_{t}$ is the market return at period $t$.

The estimation period to estimate the beta is in the range of 60 to 120 months. Second, the beta is regressed against financial leverage to obtain the un-levered beta. The beta risk is regressed against financial leverage as follows.

$$
\beta_{i}=\alpha+\delta(F L)_{i}+\varepsilon_{i}
$$

where,

$F L_{i t}$ is the financial leverage for firm $i$;

$|\varepsilon|_{i}$ is the proxy for risk from beta after controlling for financial leverage for firm $i$.

One-year growth of forecastedearnings is used in this study because the growth of actual earnings is correlated with the income-smoothing index. The forecasted-earnings growth is calculated as follows.

$$
\text { Growth }_{i t}=\left(\frac{F E_{i t}}{F E_{i t}-1}\right)-1
$$

where,

$F E_{i t}$ is one year ahead forecasted earnings from IBES for firm $i$ and time $t$;

$F E_{i t-1}$ is one year ahead forecasted earnings from IBES for firm $i$ and time $t-1$.

The results show that coefficients of forecasted earnings growth are all negative and significant except for the unrestricted regression for the U.S. firms which show insignificant results. The coefficients of adjusted beta are not significant in almost all regressions. It seems that the effect of risk from adjusted beta is correlated with the effect of financial leverage. The additions of the two variables do not alter theresults from the previous analysis. The income smoothing variable is 
only significant for the Japanese firms, but not for U.S. firms. The addition of income smoothing index variable increase the changes in the adjusted $R^{2}$ only for the Japanese firms, but not for the U.S. firms. Also, the F-test for the differential between restricted and unrestricted regressions is only significant for the Japanese firms. Overall, the results are consistent with the main analysis in the previous section.

Second, to mitigate the bias of the results caused by the unequal price (in different price range) between U.S. and Japanese firms, analysis are also conducted using a sub-sample which have the same range of price (between 7.6 and 21.7). The results show the robustness of the sample and confirm the main analysis in the previous section.

\section{Summary and Implications}

This study examines the variation in earnings-price ratios across Japanese and U.S. firms. Japanese firms have consistently lower earnings-price ratios than U.S. firms. The differences in earnings-price ratios have been primarily attributed to differences in Japanese and U.S. accounting standards. However, French and Poterba (1991), Aron (1991), and Kusuma (2004a) showed that after adjustments for differences in accounting standards, the price-earnings ratios of Japanese firms were still higher than those of U.S. firms. The objective of this study is to show that Japanese firms engage in income smoothing practices that stabilize earnings, thereby increasing Japanese investors' willingness to pay higher prices for Japanese stocks. This is possible because in Japan, firms are allowed to create and manage "reserves" that can be a tool to smooth income.

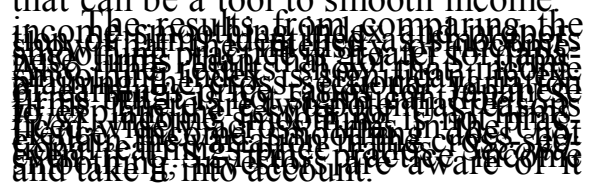

Finally, the results show that controlling for income smoothing does not completely eliminate the differences in the earnings-price ratios of Japanese and U.S. firms. That is, although income smoothing plays a role in explaining the variations of earnings-price ratios of Japanese firms, it is not the only factor that contributes to the differences in the earnings-price ratios of Japanese and U.S. firms. Other factors may play a role that is either countryspecific (such as inflationary expectations, tax regimes) or firm-specific (such as quality of earnings, real returns) as suggested by Brown (1989).

\section{Limitations and Future Research}

The adjustments used in this study follow French and Poterba (1991) and Aron (1991) which address only three items: (1) consolidation and inter-corporate ownership, (2) special reserve, and (3) depreciation. Other potential differences are ignored for reasons such as the availability of the data, the insignificance of the amounts to be 
Gadjah Mada InternationalJournal of Business, January-April 2005, Vol. 7, No. 1

adjusted, and the practicability in computing the differences of the accounting standards. Therefore, this study is a preliminary effort to raise an awareness of the potential impact of the differences in the accounting standards to the earnings-price ratios. Future research can examine in more detail the differences in the accounting standards and the measurement of the differences in order to formulate the adjustment process.

The coefficient of variations of the income smoothing method used in this study only employs five years of earnings data. Since longer earnings time series are not available, other methods to measure income smoothing are not workable. Future research can examine other income smoothing methods such as the $R^{2}$ method and the expect- ancy models of income. Ronen and Sadan (1981) give detailed explanations on the expectancy models of income.

The uses of samples from Japan and U.S. firms in this study also limit the conclusion to the Japan-U.S. case. Future research can examine the impact of differences in accounting standards on earnings-price ratios as well as other ratios or accounts of other countries.

The evidence in this study shows that income smoothing is not the only factor that explains the differences in the earnings-price ratios of Japanese and U.S. firms. Another potential area of research is to include other factors (country-specific and firm-specific) to explain the differences of the earningsprice ratios of Japanese and U.S. firms.

\section{References}

Albrecht, W. D., and F. M. Richardson 1990. Income smoothing by economy sector. Journal of Business, Finance, and Accounting 17 (5): 713-730.

Aron, P. 1991. Japanese P/E ratios in an environment of increasing uncertainty. $A$ Handbook of International Accounting (eds. Choi, Frederick): 8.1-8.18

Ashari, N., H. C. Koh, S. L. Tan, and W. H. Wong. 1994. Factors affecting income smoothing among listed companies in Singapore. Accounting and Business Research 24(96): 291-301.

Beaver, W., and D. Morse. 1978. What determines price-rarnings ratios? Financial Analysts Journal 34 (4): 65-76.

Bitner, L. N., and R. C. Dolan. 1996. Assessing the relationship between income smoothing and the Value of the Firm. Quarterly Journal of Business and Economics 35 (1): 16-35.

Bricker, R., G. Previts, T. Robinson, and S. Young. 1995. Financial analyst assessment of company earnings quality. Journal of Accounting, Auditing, and Finance 10 (3): 541-554. 
Kusuma-Do Income Smoothing Practices Explain the...

Brown, P. 1989. Invited remarks: Ball and Brown [1968]. Journal of Accounting Research 27 (Sup): 202-217.

Business Week. 1989. Who's the biggest of them all? Business Week (July 17): 139-178.

Cho, J. Y. 1994. Determinants of earnings-price ratios: A reexamination. Review of Financial Economics 3 (2): 106-120.

Choi, F. D. S., and G. G. Mueller. 1992. International Accounting. New Jersey: Prentice-Hall, Inc.

Constand, R.L., L.P. Freitas, and M. J. Sullivan. 1991. Factors affecting price earnings ratios and market values of Japanese firms. Financial Management 20 (4) (Winter): 68-79.

Craig, D., G. Johnson, and M. Joy. 1987. Accounting methods and P/E ratios. Financial Analysts Journal 43 (2): 41-45.

Douglas, M.O. 1987. Income smoothing and incentives: Empirical tests using accounting changes. Accounting Review 62 (2): 358-377.

Eckel, N. 1981. The income smoothing hypothesis revisited. Abacus 17 (1): 28-40.

Foster, G. 1986. Financial Statement Analysis. New Jersey: Prentice-Hall, Inc.

Frankel, J.A. 1991. Japanese cost of finance: A survey. Financial Management 20 (1): 95-127.

French, K. R., and J. M. Poterba. 1991. Were Japanese stock prices too high? Journal of Financial Economics 29 (2): 337-363.

Fuhrman, P. 1988. Parles-Vous P/E? Forbes (June 27): 276-278.

Goodwin, L. B. 1977. Income smoothing. CPA Journal 47 (2): 27-29.

Hector, G.1989. Cute tricks on the bottom line. Fortune (April 24): 195-200.

Huberts, L. C., and R. J. Fuller. 1995. Predictability bias in the U.S. equity market. Financial Analysts Journal 51 (2): 12-28.

Imhoff Jr., E. 1977. Income smoothing - A case for doubt. Accounting Journal (Spring): 85-100.

Kusuma, I.W. 2004a. Do accounting standards explain differences in earnings-price ratios of Japanese and U.S. firms? A Working Paper.

Paper. 2004b. Do Japanese firms smooth income more than U.S. firms? A Working

Luttman, S. M., and P. Silhan A.1995. Determinants of earnings variability. Journal of Applied Business Research 11 (1): 117-124.

Mande, V., R.G. File, and W. Kwak. 2000. Income smoothing and discretionary R\&D expenditure of Japanese firms. Contemporary Accounting Research 17 (2): 263302.

Michelson, S. E., J. Jordan-Wagner, and C. W. Wootton. 1995. A market based analysis of income smoothing. Journal of Business, Finance, and Accounting 22 (8): 11791193. 
Gadjah Mada InternationalJournal of Business, January-April 2005, Vol. 7, No. 1

Nagy, A. L., and T. L. Neal. 2001. An empirical examination of corporate myopic behavior: A comparison of Japanese and U.S. companies. International Journal of Accounting 36 (1): 91-113.

Ronen, J., and S. Sadan. 1981. Smoothing Income Numbers: Objectives, Means, and Implications. Massachusetts: Addison-Wesley Publishing Company.

Shapiro, A. C .1996. Multinational Financial Management. New Jersey: Prentice-Hall, Inc.

Sheikholeslami, M. 1994. The impact of foreign stock exchange listing on income smoothing: Evidence from Japanese firms. International Journal of Management 11 (2): 737-742.

Srinidhi, B, J. Ronen, and A. Maindiratta. 2001. Market imperfections as the cause of accounting income smoothing-The case of differential capital access. Review of Quantitative Finance and Accounting 17: 283-300.

Subramanyam, K. R. 1996. The pricing of discretionary accruals. Journal of Accounting and Economics 22 (1-3): 250-281.

Suh, Y. S. 1990. Communication and income smoothing through accounting method choice. Management Science 36 (6): 704-723.

Trueman, B., and S. Titman. 1988. An explanation for accounting income smoothing. Journal of Accounting Research 26 (Sup): 127-139.

Wang, Z., and T. H. Williams. 1994. Accounting income smoothing and stockholder wealth. Journal of Applied Business Research 10 (3): 96-104.

Zarowin, P. 1990. What determines earnings-price ratios: Revisited. Journal of Accounting, Auditing, and Finance 5 (3): 439-457. 